Received: November 14, 2017

Revision received: April 12, 2018

\title{
Applied Research on College Sports Blended Learning Based on Moodle Platform
}

\author{
Suqiong Feng \\ Sichuan Agricultural University
}

\begin{abstract}
The networking and informatization of education are the inevitable trend of the rapid development of computer technology and educational reform. Compared with other subject education, physical education is less informationalized because of its practicableness. This paper puts forward the idea of sports blended learning based on Moodle platform, aiming at combining web-based learning and traditional physical education so as to promote the reform and development of physical education in colleges and universities. The paper first introduces the research background of Moodle platform and the related theories of blended learning and compares the differences between the college sports blended learning and traditional physical education in terms of teaching process, mode and design. Then based on this, it completes the teaching design based on Moodle platform. At last, it conducts an empirical research on the application of college sports blended learning to badminton teaching, verifying its feasibility and effectiveness in college physical education.
\end{abstract}

\section{Keywords}

College Physical Education • Moodle Platform • Teaching Design $•$ Empirical Research $•$ Badminton

Suqiong, Feng, Sichuan Agricultural University, Chengdu 611130, China. Email: 2476247436@qq.com 
Since the 21st century, computer technology and computer network technology have brought tremendous changes to people's life. Computer Web technology, multimedia assistive technology, computer-assisted instruction, computer data base, big data, cloud platform have been applied theoretically and practically in the field of education, and achieved good results (Le, 2011). At present, China's education department takes the application and practice level of modern information technology in the educational system as a strategy to promote informatization and modernization of education. It is urgent to apply computer technology in education to improve teaching quality and teaching effectiveness (Zhao, 2017).

Physical education is a quite practical subject, paying more attention to face-to-face gesture and post in the process of teaching and learning. The traditional concept restricts the popularization of computer networks in sports learning, leading to its backwardness in informatization compared with other subjects (Li \& Wei, 2011). With the further development of education informatization, web-based instruction, distance teaching, webbased teaching platform, student's physique management platform, student sports performance management platform, physical education curriculum election and management platform have appeared one after another in college physical education, which has greatly improved the informatization of physical education and promoted the reform of college sports (Jensen, Nordstrom, Mostrom, Hack, \& Gwyer, 2017; Vallet et al., 2016).

Moodle (Modular Object-Oriented Learning Environment) is a typical open source teaching platform in Web2.0 era. The blended learning method is a learning method integrating "face-to-face learning" with "webbased online learning". This paper puts forward the idea of college sports blended teaching applied research based on Moodle platform. On the one hand, Moodle platform is closely linked with teacher's practical teaching. On the other hand, the blended learning meets the actual needs of physical education (Maciel, Soares, \& Amaral, 2009). The paper first introduces the research background of Moodle platform and the related theories of blended learning and compares the differences between the college sports blended education and traditional physical education in terms of teaching process, mode and design. Then based on the theoretical analysis, it designs sports blended teaching mode based on Moodle platform and chooses a public badminton course for sophomores in a university in Dalian for empirical research. At last, this paper evaluates effect of blended learning on students' learning effectiveness and performance through questionnaire survey and test and the results show that blended learning can promote the students' learning effectiveness and performance.

\section{Overview of Moodle and theories of blended learning}

\section{Overview of Moodle platform}

The Moodle platform was released by Dr. Martin from Australia in 2002 and Moodle developed rapidly in the subsequent publicity process. At present, there are over 200,000 Moodle registration sites in 175 countries all around the world (Schultz, 2012). Moodle is an open source software package so that users can further expand according to the needs under the premise of retaining the original copyright of software so as to provide virtual learning environment and web-based instruction management. Moodle mainly has the following seven functions and features:

(1) Based on advanced constructivism learning theory, it makes teaching activities become more and more 
vivid and teaching achievements more and more outstanding through a model that emphasizes dialogue, writing and interaction among learners (Zhou et al., 2017).

(2) Based on modular structure design, Moodle application is based on service-oriented architecture system and its fully modular design of system elements facilitate the design of the various activities in the development of sports curriculum.

(3) It is highly compatible, supporting for various standards that can import SCORM, AICC, IMS and other learning content package and supporting for dozens of test formats, such as WebCT and XML.

(4) It has powerful resource management function to support the word, PPT, flash, video, audio and other electronic documents.

(5) Its open source code free software allows everyone to freely use and modify the source code by following the CPL protocol.

(6) It can optimize the teaching process management. Moodle platform can configure online forums, tests, voting, homework, chat, seminars and other curriculum activities to strengthen teachers' control of course management.

(7) It enriches the communication modes. Moodle platform optimizes the teaching management whiles enriching the communication modes in the teaching process, among which forum module, seminar module and chat module provide a variety of exchanges platform for students and teachers, as well as students and students.

The Moodle platform centers on sports learners, closely links with the specific physical education practice links, and provides a flexible teaching platform for physical education through diversified modes of interaction and communication.

\section{Theories of blended learning}

Concept definition. Foreign scholars believe that blended learning is to combine face-to-face teaching and web-based learning so as to achieve valuable educational goal. Its evaluation is open by combining face-to-face teaching and computer-assisted online learning. It is believed that blended learning is to realize a teaching goal by using Web technologies (such as collaborative learning, virtual classroom live condition, streaming media, etc.). This process integrates a variety of teaching methods (such as constructivism, cognitivism and behaviourism). It is the combination of other teaching technologies and traditional face-to-face teaching and training methods, aiming at achieving the best teaching results so as to realize good learning or working results.

Domestic scholars believe that blended learning is to gather the advantages of traditional teaching modes and informatization web-based instruction modes so that it cannot only play the supervisory role of teachers in the teaching process, but promote students' initiative learning mode in learning process. Some domestic scholars think that blended learning is an effective reflection of the existing problems in the web-based learning mode. It can increase the supervisory role of teachers and achieve a better coordinated development between the two through face-to-face teaching (Claire, 2009). 
Theoretical basis of blended learning. Table 1 shows the four theoretical bases of blended learning

Table 1

The Theoretical Basis of Blended Learning

\begin{tabular}{ll}
\hline Name & Control learning behaviours through enhanced learning motivation \\
\hline Behavioural theory & Maximize the learning potential of students \\
\hline Humanistic theory & $\begin{array}{l}\text { The ability of students to construct knowledge based on their own experience } \\
\text { determines the quality of learning }\end{array}$ \\
\hline $\begin{array}{l}\text { Media Communication } \\
\text { Theory }\end{array}$ & Use different forms of media to promote communication effectiveness \\
\hline
\end{tabular}

Blended learning is based on the guidance of different theoretical study to meet the needs of different learners, learning environments, and learning goals (Stubbs, Martin, \& Endlar, 2006).

\section{Comparative analysis of college sports blended learning and traditional physical education}

A careful analysis of the differences between sports blended learning and traditional physical education can better determine the adaptability of blended learning to college physical education. The comparative analysis of the differences between the two is conducted from teaching process, teaching mode, and teaching design of physical education.

Comparison of teaching process. Compared with traditional physical education, college sports blended learning can integrate online sports learning resources while providing sports technique and physical fitness in PE class (Chen, Sheen, Yueh, Chiang, \& Chang, 2012). The differences between the two in teaching process are shown in Table 2:

Table 2

The comparison of teaching process

\begin{tabular}{lll}
\hline Item & \multicolumn{1}{c}{ Sports traditional teaching process } & \multicolumn{1}{c}{ Blended learning teaching process } \\
\hline Teaching form & $\begin{array}{l}\text { Taking physical education teachers as } \\
\text { the center, student sports technique } \\
\text { learning and body practice are the } \\
\text { main ones }\end{array}$ & $\begin{array}{l}\text { Centering on students' independent study, } \\
\text { collective study of PE practice classes and } \\
\text { independent study of individualized } \\
\text { network }\end{array}$ \\
\hline Role of teacher & Teach, monitor & Director \\
\hline Role of student & Recipient & Active learner \\
\hline $\begin{array}{l}\text { Teaching } \\
\text { media }\end{array}$ & Physical education materials & $\begin{array}{l}\text { Sports network resources, CD-ROMs, video } \\
\text { and other information }\end{array}$ \\
\hline $\begin{array}{l}\text { Teaching } \\
\text { environment }\end{array}$ & Physical education classroom & $\begin{array}{l}\text { Online classroom and physical education } \\
\text { classroom }\end{array}$ \\
\hline $\begin{array}{l}\text { Teaching } \\
\text { method }\end{array}$ & Face to Face & Face to Face, email, online chat \\
\hline $\begin{array}{l}\text { Teaching } \\
\text { content }\end{array}$ & Technical teaching content & $\begin{array}{l}\text { Technical teaching content and sports- } \\
\text { related knowledge }\end{array}$ \\
\hline
\end{tabular}

Comparison of teaching mode. Teaching mode refers to teaching activities and teaching structures established under the guidance of learning theories with certain regularity (Dwivedi \& Kumar, 2012). Comparison of teaching mode is reflected in the teaching guiding ideology, teaching objective, teaching condition, operational procedures, and teaching evaluation as shown in Table 3: 
Table 3

The Comparison of Teaching Mode

\begin{tabular}{lll}
\hline Item & \multicolumn{1}{c}{$\begin{array}{c}\text { Sports traditional } \\
\text { teaching process }\end{array}$} & \multicolumn{1}{c}{ Blended learning teaching process } \\
\hline $\begin{array}{l}\text { Teaching guiding } \\
\text { ideology }\end{array}$ & Health first & Health first \\
\hline Teach target & $\begin{array}{l}\text { The five areas of physical } \\
\text { education goals }\end{array}$ & The five areas of physical education goals \\
\hline Teach condition & $\begin{array}{l}\text { Teaching materials, } \\
\text { gymnasium }\end{array}$ & Teaching materials, gymnasium, \\
\hline $\begin{array}{l}\text { Operation } \\
\text { procedure }\end{array}$ & $\begin{array}{l}\text { Preparation section, the } \\
\text { basic part, the end part }\end{array}$ & $\begin{array}{l}\text { Technical teaching content and Prepare, explain, } \\
\text { teach, try, evaluate, support, guide, and help each } \\
\text { other }\end{array}$ \\
\hline Teach evaluation & $\begin{array}{l}\text { Classroom single } \\
\text { evaluation }\end{array}$ & \begin{tabular}{l} 
Classroom evaluation and network evaluation \\
\hline
\end{tabular}
\end{tabular}

Comparison of teaching design. The college sports blended learning is more students-centered, emphasizing the influence of learning situation and environment. It pays more attention to the excavation of sports information resources to help the growth of sports knowledge and evaluates students' physical training levels through diversified evaluation modes.

\section{College sports blended learning design based on Moodle platform}

Teaching design is a planning process and operational procedure that applies systematic methods to analyze the problems and needs of teaching, to determine teaching strategies, teaching methods, and teaching procedures and to evaluate teaching processes and results (Li., 2010). The teaching design of college sports blended learning shall fully consider the factors and characteristics of web-based teaching platform. According to modern learning theories and teaching theories combined with the characteristics of web-based instruction and traditional teaching, the teaching design conducts design and operation for physical education in colleges and universities (Tsiatsos, Konstantinidis, Demetriadis, \& Papadopoulos, 2011).

\section{Moodle online course platform teaching}

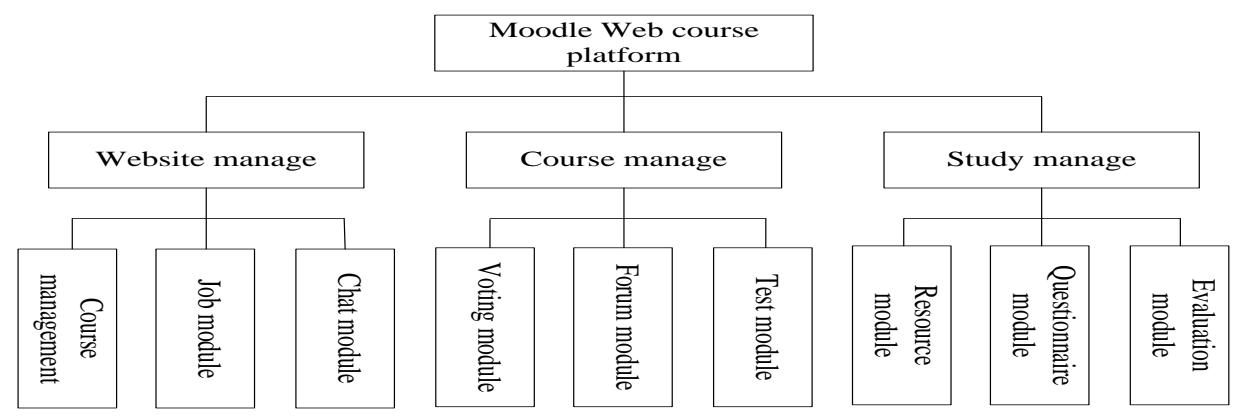

Figure 1. Moodle Online Course Platform Teaching 
As shown in Figure 1, the Moodle online course teaching platform mainly consists of three modules: website management, course management and learning management. The three modules can be subdivided into nine functional modules: course management, homework module, chat Module, voting module, forum module, test module, resource module, questionnaire module, and evaluation module (Schober \& Keller, 2012). Moodle platform is suitable for teachers to conduct course management and teaching after completing the course setting. The Moodle platform based on constructivism can provide students with class preview and analysis, sharing and training of resources in class, and expanding and interactive service after class. The open source software architecture can constantly provide new functions for students according to their needs and its powerful function ensure that it is an effective complement to traditional physical education (Zou, 2015).

\section{Teaching design of college sports blended learning}

The college sports blended learning supplements the Moodle platform from the aspects of pre-phase teaching analysis, teaching design, teaching implementation and teaching evaluation respectively. The main process is shown in Figure 2.

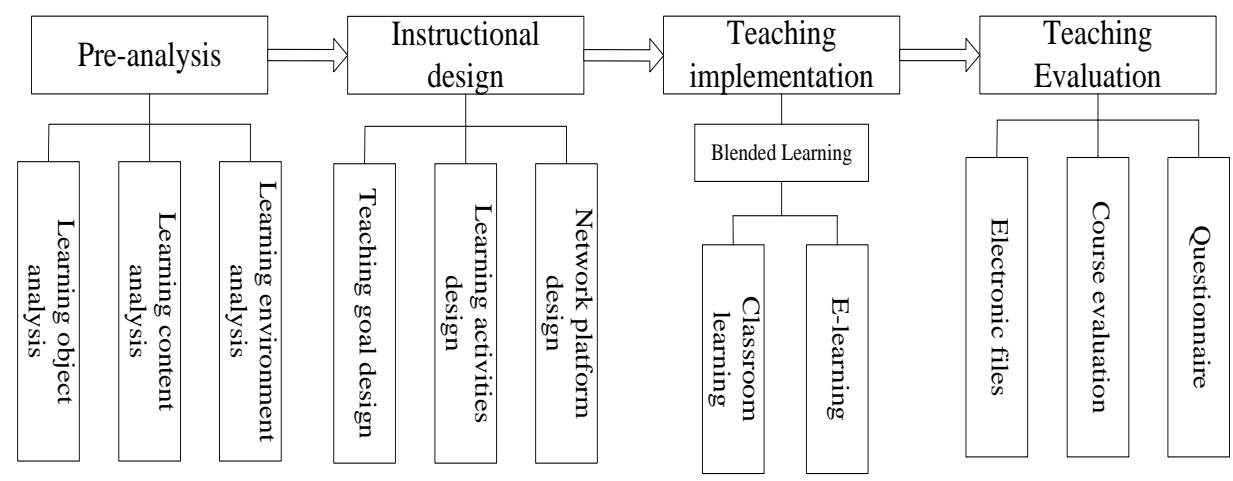

Figure 2. College Sports Blended Learning Design Procedures

Pre-phase teaching analysis mainly includes learning object, learning content and learning environment; teaching design mainly includes teaching objective, learning activity and network platform; teaching implementation is to achieve blended learning through classroom learning and web-based learning; teaching evaluation includes electronic files, course assessment, and questionnaire survey.

\section{Applied research on college sports blended learning based on Moodle platform}

This paper chooses a public badminton course for sophomores in a university in Dalian as application object and studies the impact of sports blended learning based on Moodle platform on students' sports performance and efficacy. 


\section{Overview of physical education course}

Course objectives. The objectives are to preliminarily grasp skills and rules of badminton, to understand the history of the development of badminton, to improve students' flexibility and coordination, to improve physical fitness, and to cultivate the volitional quality and the taste.

Course introduction. Course type: public elective course; class hours: 32 periods for 16 weeks; start time: first semester of sophomore year; teaching arrangements: the use of blended learning mode to exercise students' coordination for badminton and explain the main techniques of badminton. Web-based learning supplements badminton-related knowledge in the form of text, video, audio, pictures and so on.

Content design of teaching activities. Contents and presentation of badminton physical education are shown in Table 4.

Table 4

Badminton teaching media design table

\begin{tabular}{lllll}
\hline $\begin{array}{l}\text { Knowledge } \\
\text { point }\end{array}$ & \multicolumn{1}{c}{ Goal level } & \multicolumn{1}{c}{ Media } & Presenting process & Teaching activities \\
\hline $\begin{array}{l}\text { Sports injury } \\
\text { treatment }\end{array}$ & $\begin{array}{l}\text { Master sports } \\
\text { common sense }\end{array}$ & $\begin{array}{l}\text { PPT, Picture, } \\
\text { text, Video }\end{array}$ & $\begin{array}{l}\text { Interactive, answer, } \\
\text { submit homework }\end{array}$ & $\begin{array}{l}\text { Classroom teaching, } \\
\text { online self-study }\end{array}$ \\
\hline $\begin{array}{l}\text { Badminton } \\
\text { Basic Theory }\end{array}$ & $\begin{array}{l}\text { Master badminton } \\
\text { common sense }\end{array}$ & $\begin{array}{l}\text { PPT, Picture, } \\
\text { text, Video }\end{array}$ & $\begin{array}{l}\text { Interactive, answer, } \\
\text { submit homework }\end{array}$ & $\begin{array}{l}\text { Classroom teaching, } \\
\text { online self-study }\end{array}$ \\
\hline $\begin{array}{l}\text { Batting } \\
\text { technique }\end{array}$ & $\begin{array}{l}\text { Master Batting } \\
\text { technique }\end{array}$ & $\begin{array}{l}\text { Picture, text, } \\
\text { Video }\end{array}$ & $\begin{array}{l}\text { Watch video, } \\
\text { technical analysis }\end{array}$ & $\begin{array}{l}\text { Classroom teaching, } \\
\text { online self-study }\end{array}$ \\
\hline Net technology & $\begin{array}{l}\text { Master Net } \\
\text { technology }\end{array}$ & $\begin{array}{l}\text { Picture, text, } \\
\text { Video }\end{array}$ & $\begin{array}{l}\text { Watch video, } \\
\text { technical analysis }\end{array}$ & $\begin{array}{l}\text { Classroom teaching, } \\
\text { online self-study }\end{array}$ \\
\hline $\begin{array}{l}\text { Smash } \\
\text { technology }\end{array}$ & $\begin{array}{l}\text { Master Smash } \\
\text { technology }\end{array}$ & $\begin{array}{l}\text { Picture, text, } \\
\text { Video }\end{array}$ & $\begin{array}{l}\text { Watch video, } \\
\text { technical analysis }\end{array}$ & $\begin{array}{l}\text { Classroom teaching, } \\
\text { online self-study }\end{array}$ \\
\hline $\begin{array}{l}\text { Single doubles } \\
\text { tactics }\end{array}$ & $\begin{array}{l}\text { Learn badminton } \\
\text { tactics }\end{array}$ & $\begin{array}{l}\text { Picture, text, } \\
\text { Video }\end{array}$ & $\begin{array}{l}\text { Watch video, } \\
\text { technical analysis }\end{array}$ & $\begin{array}{l}\text { Classroom teaching, } \\
\text { online self-study }\end{array}$ \\
\hline
\end{tabular}

For theoretical and practical knowledge of badminton, blended learning can make online self-learning and classroom teaching complement each other to speed up students' grasp of the basics of badminton through the online learning and classroom learning of Moodle platform.

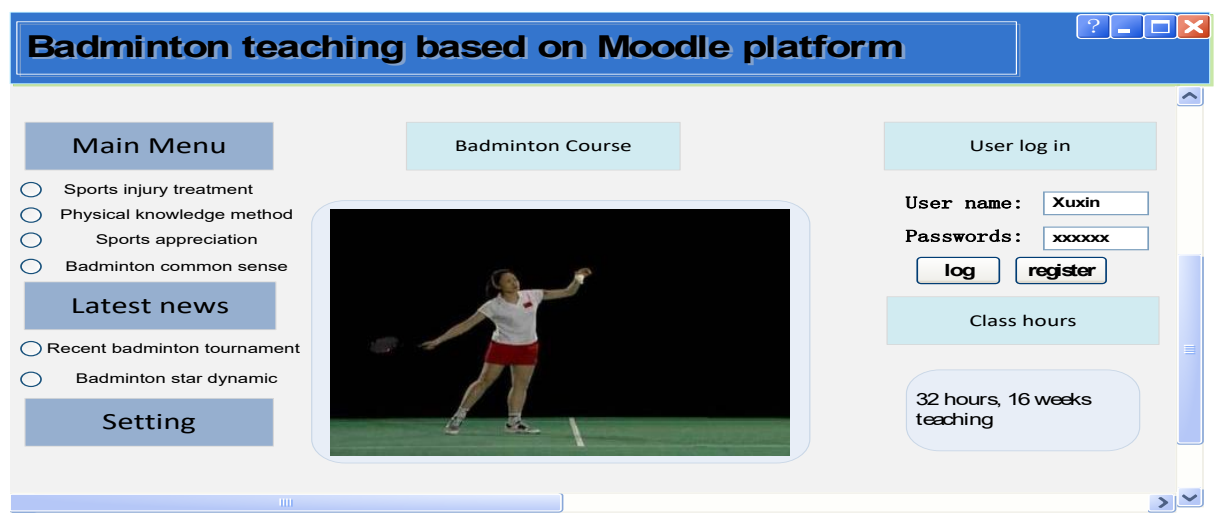

Figure 3. Badminton web-based learning interface of Moodle platform 
Web-based learning interface display of Moodle platform. Figure 3 is the badminton web-based learning interface of Moodle platform.

Users can learn about badminton knowledge and sports common knowledge at the homepage of the interface, and can look up relevant badminton sporting events and information of sports stars. After users complete the login, they can learn related badminton content as shown in Table 4.

\section{Teaching efficiency evaluation of blended learning}

Analysis of students' evaluation data. According to the characteristics of the badminton teaching course, the efficiency evaluation of students' sports learning is mainly divided into three aspects: efficiency of skill, efficiency course, and general efficacy. Through the questionnaire survey, 75 sophomores participating in the blended learning are evaluated on the above three efficacy. 1, 2, 3, 4, 5 scores are corresponding to very disagree, quite disagree, general, quite agree, very agree, which will be used to evaluate the efficiency of blended learning. The higher the score is, the stronger the efficacy is. Table 5 is a measurement table of students' efficiency of sports learning.

Table 5

Students' Efficiency of Sports Learning $(n=75)$

\begin{tabular}{lcccccc}
\hline Dimensionality & $\begin{array}{c}\text { Very } \\
\text { disagree 1 }\end{array}$ & $\begin{array}{c}\text { A little } \\
\text { disagree 2 }\end{array}$ & $\begin{array}{c}\text { General } \\
\mathbf{3}\end{array}$ & $\begin{array}{c}\text { A little } \\
\text { agree 4 }\end{array}$ & $\begin{array}{c}\text { Very } \\
\text { agree 5 }\end{array}$ & $\begin{array}{c}\text { Mean } \\
\text { value }\end{array}$ \\
\hline Skills efficiency & 0 & 5 & 15 & 20 & 35 & 4.131 \\
\hline $\begin{array}{l}\text { Course } \\
\text { efficiency }\end{array}$ & 0 & 3 & 2 & 15 & 55 & 4.626 \\
\hline $\begin{array}{l}\text { General } \\
\text { efficiency }\end{array}$ & 0 & 5 & 10 & 15 & 45 & 4.333 \\
\hline
\end{tabular}

It can be seen from the data table that the mean value of the efficacy questionnaire of three dimensions is greater than 4, indicating that blended learning method based on Moodle platform can promote the performance of sports learning.

Analysis of influence on students' sports performance. The effect of blended learning is tested with the mode of "pre-test-implementation of teaching-post-test". The main contents of the pre-test and post-test questionnaires are to evaluate the basic theoretical knowledge of badminton, the grasp and application ability of relevant badminton action knowledge and basic sports skills. The mean value of the pre-test results of blended learning teaching class is 21.43 , and the mean value of post-test is 22.56 . The overall post-test score is higher than the pre-test score, indicating that blended learning method based on Moodle platform can promote sports performance.

\section{Conclusions}

Moodle platform is an open source web-based teaching platform that is widely used worldwide and blended 
learning teaching mode meets the actual needs of college physical education. The paper combines the two to establish a college sports blended learning mode based on Moodle platform and validates its teaching effectiveness. The main research contents and conclusions paper are as follows:

(1) The paper has completed the comparison of the blended learning physical education with the traditional physical education, and has realized the college sports blended learning design based on Moodle platform.

(2) The paper has established a college sports blended learning mode based on Moodle platform which follows constructivism and other learning theories and can effectively stimulate students' learning initiative.

(3) The paper has applied the college sports blended learning mode based on Moodle platform in badminton teaching case. The application results show that the blended learning can positively promote students' sports performance and efficiency.

\section{References}

Chen, T.L., Sheen, H.J., Yueh, H.P., Chiang, F.K., \& Chang, P.W. (2012). Designing nano-biotechnology summer camp with experiential learning theory. International Journal of Engineering Education, 28(5), 1078-1087.

Dwivedi, A., \& Kumar, S. (2012). A study of physical education students of different universities. Faseb Journal, 8(2), 78-87.

Jensen, G. M., Nordstrom, T., Mostrom, E., Hack, L.M., \& Gwyer, J. (2017). National study of excellence and innovation in physical therapist education: Part 2-a call to reform. Physical Therapy, 97(7), 875-888. http://dx.doi.org/10.1093/ptj/pzx062

Le, Y. (2011). Application of computer and multimedia technology in college physical education. Circuits, Communications \& System, 1-3. http://dx.doi.org/10.1109/PACCS.2011.5990343

Li, K., \& Wei, Y. (2011). The investigation and research on the education reform concerning the common volleyball course in the institute of physical education. Biometrics, 67(2), 331-43.

Li, Y. (2010). The research on blended learning which based on moodle. Journal of Capital Normal University, 14(3), 156-167.

Maciel, D.T., Soares, W., \& Amaral, E. (2009). Moodle platform for online tutoring during internships. Medical Education, 43(11), 1113-4. http://dx.doi.org/10.1111/j.1365-2923.2009.03462.x

Schober, A., \& Keller, L. (2012). Impact factors for learner motivation in blended learning environments. International Journal of Emerging Technologies in Learning, 7(S2), 1-5. http://dx.doi.org/10.1109/icl.2012.6402063

Schultz, C. (2012). Information security trends and issues in the moodle e-learning platform: an ethnographic content analysis. Journal of Information Systems Education, 23(4), 359-371.

Stubbs, M., Martin, I., \& Endlar, L. (2006). The structuration of blended learning: putting holistic design principles into practice. British Journal of Educational Technology, 37(2), 163-175. http://dx.doi.org/10.1111/j.1467-8535.2006.00530.x

Tsiatsos, T., Konstantinidis, A., Demetriadis, S., \& Papadopoulos, P. M. (2011). Selecting and evaluating a 
learning management system: a moodle evaluation based on instructors and students. International Journal of Distance Education Technologies, 9(3), 13-30. http://dx.doi.org/10.4018/978-1-4666-2032-2.ch014

Vallet, P., Loubaton, P., Mestre, X. (2016). An improved MUSIC method for large sensor arrays, Traitement Du Signal, 33(2-3), 249-272. http://dx.doi.org/10.3166/TS.33.249-272

Zhao, X. (2017). The application of computer technology in Mongolian college English teaching. International Journal of Emerging Technologies in Learning, 12(2), 52. http://dx.doi.org/10.3991/ijet.v12i02.6044

Zhou, Y., Zhou, Y., \& Zhou, Y. (2017). Design of moodle-based podcast teaching platform for the course of aerobic gymnastics. International Journal of Emerging Technologies in Learning, 12(9), 95-104. http://dx.doi.org/10.3991/ijet.v12i09.7490

Zou, Q.C. (2015). Design and realization of the learning environment of "The Multimedia Application Base" on the platform of moodle. Journal of Hubei Correspondence University, 16, 115-116. http://dx.doi.org/10.3969/j.issn.1671-5918.2015.16-056 